Discussion Paper No. 778

ADAM SMITH'S ANSWER

TO THE FELDSTEIN-HORIOKA PARADOX: THE INVISIBLE HAND REVISITED

\author{
Ayumu Yasutomi \\ Charles Yuji Horioka
}

May 2010

The Institute of Social and Economic Research

Osaka University

6-1 Mihogaoka, Ibaraki, Osaka 567-0047, Japan 


\title{
ADAM SMITH'S ANSWER TO THE FELDSTEIN-HORIOKA PARADOX: THE INVISIBLE HAND REVISITED*
}

\author{
Ayumu Yasutomi** \\ Institute for Advanced Studies on Asia, University of Tokyo \\ and \\ Charles Yuji Horioka*** \\ Institute of Social and Economic Research, Osaka University, and \\ National Bureau of Economic Research
}

\begin{abstract}
In this paper, we show that Adam Smith pointed out the existence of the Feldstein-Horioka Paradox or Puzzle and even gave an explanation for it more than 200 years before the publication of Feldstein and Horioka (1980). Smith argues that it is the pursuit of their own security that leads owners of capital to invest their capital in their own country to as great an extent as possible and that it is the pursuit of security rather than the pursuit of profit that leads individuals to promote the good of society as a whole via the "invisible hand."
\end{abstract}

Key words: Feldstein-Horioka paradox, Feldstein-Horioka puzzle, capital mobility, capital flows, saving, investment, Adam Smith, invisible hand

Journal of Economic Literature classification numbers: B12, F21, F32

*The authors are grateful to Yoko Fukao for introducing them to each other and for her encouragement.

**Institute for Advanced Studies on Asia, The University of Tokyo, 7-3-1, Hongo, Bunkyo-ku, Tokyo 113-0033, JAPAN. E-mail: yasutomi@ioc.u-tokyo.ac.jp Telephone: 81-(0)3-5841-5849 Facsimile: 81-(0)3-5841-5898

***Institute of Social and Economic Research, Osaka University, 6-1, Mihogaoka, Ibaraki, Osaka 567-0047, JAPAN. E-mail: horioka@iser.osaka-u.ac.jp Telephone: 81-6-6879-8586/8574. Facsimile: 81-(0)6-6879-8583. 


\section{Introduction}

Exactly thirty years ago, Feldstein and Horioka (1980) pointed out that the correlation between domestic investment and saving is high even though the correlation between the two should be zero (in the case of a small economy) and equal to the country's share in world capital (in the case of a large economy) if capital is perfectly mobile across national borders. This paradox or puzzle has come to be called the "Feldstein-Horioka Paradox" or the "Feldstein-Horioka Puzzle," but in this paper, we show that it is not a paradox or puzzle at all. In fact, more than two hundred years before the publication of Feldstein and Horioka (1980), in his classic An Inquiry into the Nature and Causes of the Wealth of Nations (Smith, 1976), Adam Smith pointed out the existence of this phenomenon and even gave an explanation for it.

To preview our main conclusions, Smith argues that it is the pursuit of their own security that leads owners of capital to invest their capital in their own country to as great an extent as possible and that it is the pursuit of security rather than the pursuit of profit that leads individuals to promote the good of society as a whole via the "invisible hand.”

\section{Smith’s Views on International Capital Mobility}

In Chapter 2 of Book IV, which is entitled "Of Restraints upon the Importation from Foreign Countries of Such Goods As Can Be Produced at Home,” Smith tries to demonstrate that most of the capital of a nation is invested in that country. He writes as follows: "First, every individual endeavours to employ his capital as near home as he can, and consequently as much as he can in the support of domestic industry; provided always that he can thereby obtain the ordinary, or not a great deal less than the ordinary profits of stock (G.ed.p.454)." This is precisely the "Feldstein-Horioka Paradox or Puzzle.”

The reason Smith gives for this tendency is the desire of merchants to reduce "risk and trouble.” He writes:

Thus, upon equal or nearly equal profits, every wholesale merchant prefers naturally prefers the home trade to the foreign trade of consumption, and the foreign trade of 
consumption to the carrying trade. In the home trade his capital is never so long out of his sight as it frequently is in the foreign trade of consumption. He can know better the character and situation of the person whom he trusts, and if he should happen to be deceived, he knows better the laws and of the country from which he must seek redress. In the carrying trade, the capital of the merchant is, as it were, divided between two foreign countries, and no part of it is ever necessarily brought home, or placed under his own immediate view and command....The merchant, in order to save a second loading and unloading, endeavors always to sell in the home market as much of the goods of all those different countries as he can, and thus, so far as he can, to convert his carrying trade into a foreign trade of consumption. A merchant, in the same manner, who is engaged in the foreign trade of consumption, when he collects goods for foreign markets, will always be glad, upon equal or nearly equal profits, to sell as great a part of them at home as he can. He saves himself the risk and trouble of exportation, when, so far as he can, he thus converts his foreign trade of consumption into a home trade. Home is in this manner the centre, if I may say so, round which the capitals of the inhabitants of every country are continually circulating, and towards which they are always tending, though by particular causes they may sometimes be driven off and repelled from it towards more distant employments (G.ed.pp.454-55).”

And then the famous "invisible hand" emerges:

By preferring the support of domestic to that of foreign industry, [the merchant] intends only his own security; and by directing that industry in such a manner as its produce may be of the greatest value, he intends only his own gain, and he is in this, as in many other cases, led by an invisible hand to promote an end which was no part of his intention. Nor is it always the worse for the society that it was no part of it. By pursuing his own interest he frequently promotes that of the society more effectually than when he really intends to promote it (G.ed. p.456).”

Thus, Smith argues that it is the owner of capital's concern about her own security, not her concern about the rate of profit, that leads her to invest her capital domestically to as great an extent as possible.

Note, moreover, that, contrary to common belief, this is the only usage the term "invisible hand" in the entire book. Thus, Smith argues that what leads individuals to promote the good of society as a whole is not the pursuit of profit but the pursuit of 
security! And it is this tendency toward risk-aversion and the dominance of this tendency vis-à-vis the tendency to pursue profits that causes capital to be immobile between countries.

Granted, capital markets have become much more liberalized than during the days of Adam Smith, but the higher than expected coefficient in Feldstein and Horioka-type regressions shows that what Adam Smith wrote more than 200 years ago applies even today.

\section{Conclusion}

In this paper, we show that Adam Smith pointed out the existence of the Feldstein-Horioka Paradox or Puzzle and even gave an explanation for it more than 200 years before the publication of Feldstein and Horioka (1980). Smith argues that it is the pursuit of their own security that leads owners of capital to invest their capital in their own country to as great an extent as possible and that it is the pursuit of security rather than the pursuit of profit that leads individuals to promote the good of society as a whole via the "invisible hand." 


\section{References}

Feldstein, Martin, and Horioka, Charles Yuji (1980), "Domestic Saving and International Capital Flows,” Economic Journal, vol. 90, no. 358 (June), pp. 314-329.

Smith, Adam (1976), An Inquiry into the Nature and Causes of the Wealth of Nations, volume 2 of Adam Smith, The Glasgow Edition of the Works and Correspondence of Adam Smith (Oxford: Oxford University Press). 